\title{
POLA KOMUNIKASI INTERNAL BRAJAMUSTI MENJELANG PILKADA KOTAMADYA YOGYAKARTA 2017
}

\author{
Dani Fadillah \\ Ilmu Komunikasi Universitas Ahmad Dahlan
}

\begin{abstract}
This study attempts to do an examination of communication dynamics occurring in internal Brajamusti as a pro football team PSIM Jogja during the election of a candidate mayor and municipal deputy mayor Yogyakarta.This study was conducted using descriptive qualitative approach.Type of research is doing check deeply the dynamics of what happens ranging from communication activities which is a formal culturally to eventually become Brajamusti the agreement. Some activity carried out such as by collecting and assess case, floated issues, even, and so on. Do the interview with the members and Brajamusti's lead, an analysis of interviews, mapped problems faced, and formulated conclusion.
\end{abstract}

\begin{abstract}
Abstrak
Penelitian ini bertujuan untuk melakukan pengamatan terhadap dinamika komunikasi yang terjadi dalam internal Brajamusti sebagai wadah pendukung tim sepak bola PSIM Jogja semasa pemilihan calon Walikota dan Wakil Walikota Kotamadya Yogyakarta. Penelitian ini dilaksanakan dengan menggunakan pendekatan deskriptif kualitatif. Tipe dari penelitian ini adalah melakukan penelaahan secara mendalam terhadap dinamika yang terjadi mulai dari aktifitas komunikasi yang bersifat kultural hingga formal yang pada akhirnya menjadi kesepakatan Brajamusti sebagai organisasi.Beberapa aktivitas dilaksanakan seperti mengumpulkan dan mengkaji kasus-kasus, isu yang dilontarkan, even, dan sebagainya. Melakukan interview dengan para anggota dan pimpinan Brajamusti, melakukan analisis terhadap hasil wawancara, memetakan permasalahanpermasalahan yang dihadapi, dan merumuskan kesimpulan.
\end{abstract}

Keywords: Communication Intenal, Brajamusti, Election

\section{PENDAHULUAN}

Sepak bola dan politik merupakan hal yang berbeda, yang satu adalah oleh raga dan yang satu lagi adalah arena perebutan kepentingan, akan tetapi tampaknya meski pun berbeda kedua hal ini tidak bias dipisahkan begitu saja. Di berbagai belahan dunia secara lintas generasi sepak bola senantiasa tidak bisa lepas dari yang namanya politik dan politik pun tidak bias jauh-jauh dari yang namanya sepak bola, seperi yang dilakukan oleh Jendral Franco di Spanyol (Real Madrid), Mussolini di Italia (Lazio), hingga Pangeran William di Inggris (Aston
Villa). Bahkan secara umum klub sepak bola beserta wadah supporter yang dimilikinya memiliki dasar ideologi dan kepentingannya masing-masing (Syahputra, 2016).

Fanatisme yang dimiliki oleh para pendukung sepak bola merupakan energi luar biasa serta menggiurkan bagi para politisi, sehingga para politisi pun tak segan mendekatkan diri dengan sepak bola serta berani melakukan investasi besar-besaran bagi klub agar menjadi sosok yang dicintai para penggemar dengan harapan akan mendapatkan dukungan bagi setiap langkah politis yang akan diambilnya. 
Begitu pula dengan klub dan para pendukungnya, politisi terlihat sebagai sosok yang mampu memberikan angin segar bagi perkembangan klub demi meraih prestasi, sehingga akan terlihat sebagai sebuah hal yang mubazir jika sampai menolak kalau ada politisi yang mendekat. Kesimpulannya hubungan antara sepak bola dan para politisi bersifat mutualisme.

Di Indonesia pun kondisinya tidak jauh berbeda dengan banyaknya klub yang tidak bisa lepas dari kepentingan politik, sebut saja Persipura Jayapura (Benhur Tomy Mano, Golkar), Persiba Bantul (Idham Samawi, PDIP), Pelitajaya Karawang (Bakrie), dan sebagainya. Bahkan Futsal pun mulai dilirik untuk kepentingan politik, terlihat dengan terpilihnya Hary Tanoe Soedibjo (Perindo) sebagai Ketua Asosiasi Futsal Indonesia pada 2014 silam.

Menjelang Pemilihan Walikota dan Wakil Walikota Yogyakarta pada tahun 2017 dinamika komunikasi yang beraroma politis pun muncul di internal Brajamusti sebagai wadah supporter PSIM Jogja. Munculmya dua pasang calon Kepala Daerah Kotamadya Yogyakarta yang terdiri dari pasangan Imam Priyono-Achmad Fadhlil dan pasangan Haryadi Suyuti-Heroe Poerwadi melahirkan dinamika komunikasi tersendiri di internal Brajamusti.

Sebagai organisasi non partisan selayaknya Brajamusti bersifat netral namun Brajamusti harus menentukan sikap dan sikap itu akan terbentuk dari komunikasi yang terjadi di internal mereka. Oleh karena itu lah peneliti tertarik untuk melakukan kajian terhadap dinamika komunikasi internal Brajamusti menjelang Pilkada di Kotamadya Yogyakarta 2017.

\section{KAJIAN PUSTAKA}

\section{Alur Pesan dalam Organisasi}

Ada beberapa faktor kunci dalam pengorganisasian, misalnya saja: struktur, perilaku dan lingkungan. Weick juga menganggap faktor-faktor tersebut sebagai suatu yang penting, akan tetapi faktor tersebut dipandang dalam perspektif yang berlainan. Jika di dalam teori terdahulu, struktur dipandang sebagai sebagai suatu hierarki, kebijakan serta rancangan pengorganisasian, maka Weick menganggap bahwa struktur merupakan suatu aktivitas dan serta lebih spesifik lagi yakni aktivitas komunikasi. Struktur ditentukan oleh perilaku yang saling bertautan.

Dari hal tersebut, kita dapat ambil gambaran bahwa suatu organisasi kerap kali dipandang sebagai representasi dari ketua atau pimpinannya. Kerap kali apa yang menjadi perilaku dari sang pemimpin mempunyai pengaruh yang besar terhadap anggota-anggota organisasinya. Hal ini dikarenakan, biasanya dominasi dari pemimpin sangatlah kuat maka apa yang menjadi kemauan pemimpin harus diikuti pula oleh setiap anggota organisasi. Jika anggota masih menginginkan berada dalam organisasi tersebut, maka tentunya anggota harus menuruti keinginan dari pemimpinnya.

Weick (1979), mendefinisikan suatu pengorganisasian sebagai suatu gramatika yang kemudian disahkan secara mufakat untuk mengurangi ketidakjelasan dengan menggunakan perilaku-perilaku bijaksana yang bertatutan. Dalam hal tersebut, berarti dapat dikatakan bahwa suatu proses pengorganisasian harus dilaksanakan secara musyarawah untuk mencapai kata sepakat. Oleh karenanya, setelah adanya kesepakatan hendaknya dapat dijalankan oleh masing-masing orang yang berada di dalam organisasi tersebut dan hendaknya perilaku-perilaku dari setiap orang dapat saling mempengaruhi guna melaksanakan apa yang sudah disepakati tersebut.

Selain itu, Weick tidak melakukan pemisahan antara organisasi dan lingkungan. Dia berpendapat, bahwa orang-orang yang terlibat secara aktif dalam menciptakan dunia mereka. Setiap anggota organisasi, tidak hanya bereaksi namun juga bereaksi, dan menciptakan. Poin utama dalam hal ini adalah, daripada membicarakan mengenai penyesuaian dengan suatu 
lingkungan eksternal, mungkin akan lebih tepat menyatakan bahwa di dalam proses pengorganisasian terdiri dari penyesuaian dengan lingkungan yang diperankan, di mana merupakan suatu yang terbentuk berdasarkan pada tindakan-tindakan dari aktor-aktor yang saling tergantung (Weick, 1979: 27).

Dengan demikian dapat diambil benang merah, bahwa setiap aktor akan membentuk lingkungan mereka sendiri berdasarkan pada kebutuhan yang ada. Misalnya saja pada lingkungan kantor, setiap orang yang mempunyai hobi untuk membaca maka kemudian akan berkomunikasi dan membentuk lingkungan baru dengan orang yang mempunyai hobi membaca juga, sebaliknya orang yang mempunyai hobi menonton sepakbola maka juga akan membentuk lingkungan pada orang yang mempunyai hobi menonton sepak bola. Meskipun adanya berbedaan pada hobbi, namun tentu karena mereka berada di dalam lingkungan yang lebih besar (kantor) maka mereka juga akan saling menghormati dan menyesuaikan diri terhadap apa yang menjadi hobbi dan kesenangan dari para anggota suatu kantor.

Berbicara mengenai komunikasi organisasi berarti mengkaji tentang bagaimana proses perpindahan informasi dari seseorang yang mempunyai otoritas tinggi kepada yang lebih rendah (komunikasi ke bawah), otoritas rendah ke yang lebih tinggi (komunikasi ke atas), dan yang memiliki otoritas sama (komunikasi horizontal), serta yang tidak mempunyai hubungan langsung di dalam struktur organisasi baik itu bawahan ataupun atasan melainkan berlainan divisi (diagonal).

Setiap jenis komunikasi tersebut, tentu mempunyai proses yang berbeda-beda. Oleh karena itu, dibutuhkan suatu pola organisasi yang nantinya dapat memberikan peluang bagi terjadinya komunikasi empat arah tersebut. Arah komunikasi mempunyai peran sebagai landasan kerja di mana komunikasi nantinya dapat dilaksanakan dalam suatu organisasi.

\section{Komunikasi ke Bawah (Downward Communication)}

Komunikasi ke bawah terjadi pada orang yang mempunyai otoritas tinggi kepada yang lebih rendah. Adapun bentuk-bentuk dari komunikasi ke bawah, misalnya saja: instruksi, memo resmi, pernyataan mengenai kebijakan perusahaan, prosedur, pedoman kerja, dan penguman perusahaan.

Di dalam realitas, masalah yang ada di dalam komunikasi ke bawah ini biasanya sangatsulituntukmenginterpretasikanpesan. Hal ini terjadi karena umumnya seorang pemimpin tidak dapat mengkomunikasikannya dengan baik pada bawahan yang notabene mempunyai tingkat pendidikan rendah. Sebagai contoh, para karyawan kerap kali mengeluhkan terhadap ketidakjelasan intsruksi yang diberikan oleh pimpinan untuk melakukan suatu tindakan. Untuk mensiasati hal tersebut, seorang pimpinan seharusnya melakukan komunikasi ke bawah dengan tegas dan langsung pada maksud yang dituju.

Ada beberapa jenis yang terjadi di dalam komunikasi dari atasan dan bawahan (Katz dan Kahan dalam Wayne Pace, 2005). Petunjuk mengenai bagaimana melakukan suatu pekerjaan; Petunjuk mengenai dasar pemikiran untuk melakukan suatu pekerjaan; Petunjuk mengenai kebijakan serta praktekpraktek yang terjadi di dalam organisasi; Petunjuk mengenai kinerjapegawai;Petunjuk untuk mengembangkan rasa memiliki tugas (sense of mission).

Komunikasi ke bawah tidak hanya mencakup pada metode yang digunakan untuk menginformasikan berbagai informasi ke bawah, akan tetapi juga pada bagaimana informasi dapat diterima dengan baik. Oleh karenanya, diperlukan adanya strategi khusus pada komunikasi ke bawah, yang tentunya tidak hanya mencakup pada pengeluaran sumber daya langsung tetapi juga sumber daya psikis dan emosional. 


\section{Komunikasi ke Atas (Upward Communication)}

Komunikasi jenis ini, berarti informasi mengalir dari tingkat yang lebih rendah (bawahan) ke tingkat lebih tinggi (penyelia). Tidak hanya atasan yang berhak berkomunikasi dengan bawahannya, namun bawahan pun juga hendaknya selalu berkomunikasi dengan atasan. Komunikasi yang dilakukan bawahan kepada atasan, bisa jadi berupa feedback atas informasi yang dilakukan oleh atasan baik berupa petunjuk ataupun perintah mengerjakan sesuatu.

Menurut Wayne Pace (1998: 190), berikut adalah beberapa hal, yang menyebabkan komunikasi ke atas dianggap penting untuk dilakukan: Aliran informasi ke atas memberi informasi berharga untuk pembuatan keputusan oleh mereka yang mengarah organisasi dan mengawasi kegiatan orangorang lainnya. (Sharma, 1979). Komunikasi ke atas memberitahukan kepada penyelia kapan bawahan mereka siap menerima informasi dari mereka dan seberapa baik bawahan menerima apa yang dikatakan kepada mereka (Planty dan Machaver, 1952).

Komunikasi ke atas memungkinkan bahkan mendorong omelan dan keluh kesah muncul ke permukaan sehingga penyelia tahu apa yang menggangu mereka yang paling dekat dengan operasi-operasi sebenarnya. (Conboy, 1976). Komunikasi ke atas menumbuhkan apresiasi dan loyalitas ke pada organisasi dengan memberi kesempatan kepada pegawai untuk mengajukan pertanyaan dan menyumbang gagasan serta saransaran mengenai operasi organisasi (Planty dan Machaver, 1952).

Komunikasi ke atas mengizinkan penyelia untuk menentukan apakah bawahan memahami apa yang diharapkan dari aliran informasi ke bawah (Planty dan Machaver, 1952). Komunikasi keatas membantu pegawai mengatasi masalah pekerjaan mereka dan memperkuat keterlibatan mereka dengan pekerjaan mereka dan dengan organisasi tersebut (Hardiman, 2009).

Setiap pimpinan organisasi tentu menginginkan anggotanya untuk aktif dalam mengembangkan organisasinya. Sebagaimana disebutkan di atas, adanya komunikasi ke atas ini, diharapkan para bawahan (anggota) organisasi terlibat aktif di dalam setiap kebijakan yang diambil oleh pimpinan. Apabila hal-hal yang tidak dimengerti oleh bawahan, maka hendaknya bawahan tidak segan-segan untuk menanyakannya kepada atasan. Di era teknologi ini, tentu akan memudahkan proses komunikasi ke atas tersebut. Jika atasan sedang sibuk, maka bawahan tidak perlu menunggu waktu untuk bertatap muka langsung guna menanyakan suatu hal, namun bisa melalui chatting, blackberry messenger, whatsapp dan lain sebagainya.

\section{Komunikasi Horisontal}

Komunikasi jenis ini merupakan proses penyampaian informasi dari anggota organisasi yang mempunyai kesejajaran kedudukan. Dalam hal ini adalah setiap anggota yang ditempatkan di dalam unit kerja yang sama maka mereka dapat saling berinteraksi (komunikasi) secara bebas. Misalnya saja di lingkungan Universitas yakni suatu program studi, maka setiap dosen yang berada di program studi tersebut dapat saling berkomunikasi. Sedangkan komunikasi yang terjadi antara dosen satu program studi dengan program studi lainnya disebut komunikasi diagonal.

Menurut Harun (2008:49-50), ada beberapa alasan yang menyebabkan terjadinya adanya komunikasi horizontal, sebagai berikut; satu, untuk mengkoordinasikan penugasan kerja. Setiap anggota dapat melakukan koordinasi guna membicarakan mengenai suatu penugasan yang diberikan oleh atasan. Misalnya, saja: pada acara lustrum, stadium general ataupun suatu seminar. Maka demi kelancaran acara tersebut, hendaknya para anggota organisasi mengkomunikasikan antara satu tugas dengan tugas lainnya.

Dua, berbagi informasi mengenai rencana kegiatan. Hal ini memungkinkan setiap anggota organisasi untuk dapat berbagi gagasan mengenai suatu event yang 
akan diselengggarakan. Setiap orang tentu mempunyai pemikiran yang berbeda-beda, dan apabila dapat didiskusikan bersama maka pemikiran tersebut tentu saja dapat lebih baik.

Tiga, untuk memecahkan masalah. Hidup ini tidak dapat dilepaskan dari apa yang disebut dengan masalah, maka apabila masalah tersebut terjadi di dalam suatu organisasi hendaknya dapat diselesaikan bersama dengan adanya peran aktif dari setiap anggota.

Empat, untuk memperoleh pemahaman bersama. Sebagaimana disebut di atas, bahwa pemikiran satu orang dengan orang lain tentu tidak sama. Komunikasi mempunyai peranan penting bagi terciptanya suatu pemahaman bersama. Oleh karenanya, setiap anggota organisasi diharapkan mampu bersikap terbuka untuk membicarakan mengenai setiap perbedaan tersebut.

Lima, untuk mendamaikan, berunding, dan menganai perbedaan. Setiap individu seringkali mengembangkan pilihan dan prioritas yang kemudian menyebabkan adanya ketidakpuasan. Oleh sebab itu, adanya komunikasi antara anggota organisasi dapat menjadi solusi dalam upaya untuk mendamaikan persoalan yang ada.

Enam, untuk menumbuhkan dukungan antar persona. Dukungan seorang rekan kerja sangat berarti bagi kesuksesan di dalam meraih tujuan organisasi. Oleh karena itu, seharusnya para anggota organisasi selalu terbuka terhadap hal-hal yang dialami untuk memperoleh dukungan dari anggota organisasi yang lain. Saat ada waktu luang, maka hendaknya dapat memanfaatkannya untuk dapat berkomunikasi guna meningkatkan keakraban diantara para anggota.

\section{Komunikasi Diagonal (Diagonal Communication)}

Sebagaimana sudah di sebutkan di atas, dalam suatu lingkungan kerja kita tidak hanya berkomunikasi dengan orang-orang yang berada dalam divisi kita. Akan tetapi, kita juga dituntut untuk dapat berkomunikasi dengan orang yang berbeda divisi. Meskipun jenis ini merupakan suatu jalur komunikasi yang paling sedikit digunakan, akan tetapi komunikasi diagonal juga merupakan hal yang penting terutama apabila ada individu yang mengalami kesulitan berkomunikasi dengan jalur yang lain.

Dapat diambil contoh dalam komunikasi jenis ini, misalnya saja pada seorang bagian keuangan di mana dia mempunyai tugas untuk membuat laporan keuangan bulanan. Maka untuk membuat laporan tersebut, dia juga harus berkomunikasi dengan divisi pemasaran (marketing) untuk menanyakan mengenai besarnya dana yang dikeluarkan untuk kegiatan pemasaran termasuk hasil yang telah dicapai. Oleh karena hal tersebut, tidaklah mungkin individu hanya melakukan komunikasi di dalam satu divisi saja, melainkan juga berkomunikasi dengan divisi lainnya yang semua saling berkesinambungan.

\section{METODE}

Metode yang digunakan dalam penelitian ini adalah metode deskriptif, dengan jenis studi korelasional.Pendekatan yang digunakan dalam penelitian ini adalah pendekatan kuantitatif. Penelitian deskriptif (descriptive research) adalah suatu metode penelitian yang ditujukan untuk menggambarkan fenomena-fenomena yang ada, yang berlangsung pada saat ini atau saat yang lampau (Sukmadinata, 2008: 17). Oleh karena itu penelitian ini memonitor apa yang terjadi dalam internal tubuh Brajamusti selama periode penjaringan bakal calon oleh partai hingga apa saja hal yang terjadi setelah KPU menetapkan nama-nama calon yang berlaga dalam Pilkada di Kotamadya Yogyakarta tahun 2017.

Penelitian ini berlangsung di Wisma PSIM, Wisma Soeratin, Komplek Mandala Krida Yogyakarta, Stadion Sultan AGung Bantul, serta di tempat-tempat yang biasanya dijadikan tempat berkumpul oleh wadah-wadah supporter PSIM Jogja. Proses monitoring dan pengumpulan datadata sudah dilakukan sejak bulan Mei 2017 
ketika nama-nama yang dijagokan untuk maju sebagai kepala daerah di Kotamadya Yogyakarta muncul di permukaan hingga tanggal 15 April 2017 saat pencoblosan dilakukan.

Dalam penelitian ini data yang dikumpulkan antara lain melalui rekaman arsip, wawancara, dan observasi langsung. Peneliti telah mewawancarai informan yang dapat mendukung rumusan masalah diantaranyaadalah para pengurus Brajamusti, senior dan alumni kepengurusan Brajamusti serta tokoh-tooh tertentuyang terkait dengan Brajamusti dan namanya disebut-sebut akan maju dalam Pilkada sebagai calon Walikota Kotamadya Yogyakarta.

\section{HASIL DAN PEMBAHASAN}

\section{Sepak Bola dan Politik di Indonesia}

Junaedi (2011: 6) pernah mengungkapkan bahwa sepak bola sudah akrab menjadi media komunikasi politik para politisi. Pemanfaatan sepak bola sebagai media komunikasi politik bisa dilihat dari penggunaan Anggaran Pendapatan dan Belanja Daerah (APBD) untuk membiayai klub yang berlaga di Liga Indonesia. Para kepala daerah berusaha mengembangkan popularitasnya dengan membiayai klub yang berlaga di Liga Indonesia apalagi setelah pemilihan kepala daerah dilakukan secara langsung. Pemilihan kepala daerah secara langsung ini menuntut adanya popularitas yang tinggi dari para aktor politik yang berkompetisi.

Misalnya sebagaimana yang terjadi pada masa kepemimpinan Sutiyoso menjabat sebagai Gubernur Jakarta kesebelasan Persija Jakarta berhasil menggapai pretasi tinggi karena mendapat dukungan besar dari Sutiyoso sehingga tidak aneh jika Sutiyoso berhasil menjabat Gubernur Jakarta selama dua periode. Popularitasnya yang tinggi sebagai Gubernur yang peduli dan royal dalam membelanjakan anggaran untuk membeli pemain bintang demi prestasi klub, hasilnya dia begitu populer meski pun bukan putra daerah.

SelainitupadasaatpemiluPresidentahun 2009 pun M. Jusuf Kalla memanfaatkan sepak bola sebagai bahan kampanye politiknya dimana dia merekrut duo primadona sepak bola tanah air saat itu yaitu Bambang Pamungkas dan Ponaryo Astaman sebagai endorse dalam iklannya. Juga ada iklan politik dari Sutrisno Bachir selaku mantan Ketua Umum Partai Amanat Nasional yang menjadikan latarbelakang permainan sepak bola sebagai materi iklannya.

Berbagai fenomena diatas secara jelas menjadi bukti bagaimana relasi sepak bola dan komunikasi politik di Indonesia. Popularitas sepak bola sebagai olah raga yang paling populer di Indonesia sejalan dengan popularitas sepak bola sebagai cabang olah raga yang dimanfaatkan sebagai media komunikasi politik. Prestasi tim nasional yang barangkali miskin prestasi tidak berarti secara otomatis sepak bola kehilangan keefektifitasannya sebagi sarana komunikasi politik. Fanatisme yang luar biasa pada sepak bola menutupi keterpurukan prestasi tim nasional, dimana fanatisme ini lah yang kemudoan dimanfaatkan sebagai media komunikasi politik (Junaedi, 2009: 10).

Untuk di Kotamadya Yogyakarta sendiri PSIM Jogja memiliki dua wadah supporter yaituBrajamusti dan The Maiden dimana masing-masing dari keduanya memiliki masis massa dan organisasi under bow dengan karakteristiknya masing-masing. Untuk penelitian yang dilakuka kali ini peneliti menjadikan Brajamusti sebagai subyek kajian dikarena Brajamusti merupakan wadah supporter pertama PSIM Jogja dan secara kuantitas memiliki basis massa yang jauh lebih banya dibandingkan dengan kelompok yang lain di Kotamadya Yogyakarta.

Secara bahasa Brajamusti sendiri merupakan akronim dari Brakyat Jogja Mataram Utama Sejati, sedangkan berdasarkan kisah Mahabharata Brajamusti merupakan senjata jurus atau pamungkas milik Gatotkaca Putra Bima dalam bentuk aji-ajian, oleh karena itu lah kehadiran Brajamusti di stadion memberikan dukungan pada PSIM Jogja yang sedang bertanding layaknya menjadi sumber kekuatan tersendiri bagi klub yang mereka dukung. Nyanyian serta yel-yel yang diteriakkan oleh 
Brajamusti seolah menjadi aji-ajian yang membangkitkan semangat para pemain PSIM Jogja dan menciutkan nyali para lawannya.

Brajamusti memiliki tempat tersendiri bagi para pendukung PSIM Jogja yang berasal dari kaum perempuan, wadah itu bernama Brajamolek yang merupakan akronim dari Brakyat Jogja Modern dan Intelek. Disinilah para wanita pendukung PSIM Jogja berkoordinasi, kehadiran Brajamolek sebagai wadah supporter perempuan turut memberikan warna tersendiri. Sebagaimana data yang peneliti dapatkan dari wawancara yang dilakukan terhadap Brajamolek mereka bukan lah sebatas tempat berkumpul para perempuan pendukung klub sepak bola (PSIM Jogja) bukan kelompok perempuan penyuka pemain bola, kaena itu mereka pun memiliki kode etik dan aturan yang harus ditaati oleh semua anggotanya. Latar belakang Brajamolek sendiri sangat bervariasi baik dari background pendidikan, ekonomi dan status sosialnya. Oleh karena itu lah selain Brajamusti, Brajamolek juga menjadi salah satu sumber informasi penting dari penelitian yang peneliti lakukan.

\section{Komunikasi Internal Jelang Pemilihan}

Sebelum penetapan calon Walikota dan Bakal Calon walikota Kotamadya Yogyakarta pada tanggal dinamika yang terjadi di internal Brajamusti cukup dinamis. Saat itu muncul beberapa nama yang digadang-gadang sebagai bakal calon Walikota Yogyakarta seperti pasangan incumbent Haryadi Suyuti dan Imam Priyono, para pejabat publik dan petinggi partai seperti Heroe Poerwadi, Achmad Fadli, Zuhrif Hudaya, hingga tokoh masyarakat seperti Poerbokusumo (saudara Sri Sultan Hamengkubuwono X) dan Ahmad Syauqi Soeratno (Kader Muhammadiyah sekaligus mantan General Manager PSIM Jogja) serta beberapa nama lain yang terus muncul karena dinilai layak untuk dipertibangkan menjadi orang nomor satu di Yogyakarta.

Para bakal calon, simpatisan dan timses yang sudah dipersiapkan pun saat itu pun telah bergerilya ke berbagai kelompok dan lapisan masyarakat untuk mendapatkan dukungan agar para bakal calon dilirik oleh para partai yang memiliki hak untuk mengusung calon Walikota, mengingat dari sejumlah partai yang menduduki DPRD Kota Yogyakarta hasil Pemilu 2014 hanya PDIP yang dapat mengusung calon tanpa harus berkoalisi dengan partai politik lainnya.

Dalam Pemilu DPR RI caleg terpilih adalah mereka yang berasal dari parpolparpol yang lolos 2,5\% PT (Parliament Threshold).Ketentuan 2,5 \% PT ini tidak berlaku untuk Pemilu DPRD (Provinsi \& Kab/Kota), dengan demikian kompetisi memperebutkan kursi DPRD akan menjadi lebih terbuka bagi caleg yang berasal dari partai kecil maupun partai baru. Ini berarti Pemilu DPRD menjadi semakin kompetitif diantara para caleg yang berasal dari ke-38 Parpol (kecuali di NAD, ditambah 6 parpol lokal).

Untuk menentukan perolehan kursi DPRD (Provinsi \& Kab/Kota) maka terlebih dahulu diketahui jumlah suara per parpol, selanjutnya kursi dibagikan kepada parpol yang terbagi atas BPP; yaitu parpol yang mencapai atau melebbihi BPP (kita sebut saja Parpol BPP). Bila terdapat sisa kursi, maka sisa kursi akan dihabiskan dengan cara membagikan sisa kursi kepada parpol-parpol (baik parpol BPP maupun parpol non BPP) dengan mengurutkan suara atau sisa suara parpol-parpol tersebut berdasarkan sistem rangking.

Dengan demikian, tahapan perhitungan perolehan kursi parpol pada Pemilu DPRD (Provinsi \& Kab/Kota) terdiri atas 2 (dua) tahap, yakni sistem BPP (Tahap I) dan sistem rangking (Tahap II, bila terdapat sisa kursi).Hasil Pemilu Legislatif DPRD Kota Yogyakarta 2014 bisa kita lihat pada tabel.

Dari data diatas dapat dilihat selain PDIP partai-partai seperti PKS, Golkar, Gerindera, PAN dan PPP harus membangun koalisi, sedangkan Nasdem dan PD harus bersedia untuk menjadi pendukung koalisi karena hanya memiliki satu kursi. Kemudian partaipartai yang ada diluar batas ambang bawah yang tidak memiliki kursi harus berbesar hati untuk tidak memiliki wakil di DPRD Kota Yogyakarta dan hanya bisa menunggu uluran 


\begin{tabular}{|c|l|c|c|}
\hline No & \multicolumn{1}{|c|}{ Nama Partai } & $\begin{array}{c}\text { Jumlah } \\
\text { Kursi }\end{array}$ & $\begin{array}{c}\text { Perolehan } \\
\text { Suara }\end{array}$ \\
\hline 1 & Partai Nasional Demokrat (Nasdem) & 1 & 7.875 \\
\hline 2 & Partai Keadilan Sejahtera (PKS) & 4 & $\mathbf{1 8 . 5 8 7}$ \\
\hline 3 & Partai Demokrasi Indonesia Perjuangan (PDIP) & 15 & 77.236 \\
\hline 4 & Partai Golongan Karya (Golkar) & 5 & $\mathbf{1 7 . 7 6 3}$ \\
\hline 5 & Partai Gerakan Indonesia Raya (Gerindera) & 5 & $\mathbf{2 6 . 9 5 9}$ \\
\hline 6 & Partai Demokrat (PD) & 1 & $\mathbf{1 3 . 0 3 1}$ \\
\hline 7 & Partai Amanat Nasional (PAN) & 5 & 30.952 \\
\hline 8 & Partai Persatuan Pembangunan (PPP) & 4 & $\mathbf{2 1 . 0 8 0}$ \\
\hline 9 & Partai Hati Nurani Rakyat (Hanura) & 0 & 3.652 \\
\hline 10 & Partai Kebangkitan Bangsa (PKB) & 0 & 3.214 \\
\hline 11 & Partai Bulan Bintang (PBB) & 0 & $\mathbf{1 . 2 3 7}$ \\
\hline 12 & Partai Kebnagkitan dan Persatuan Indonesia (PKPI) & 0 & $\mathbf{1 . 0 5 1}$ \\
\hline & Jumlah & 40 & 203.665 \\
\hline
\end{tabular}

tangan dari para pemilik kursi di parlemen.

Dari berbagai nama yang muncul sebagai bakal calon Walikota di Kotamadya Yogyakarta ada dua nama yang sering muncul dikalangan internal Brajamusti, yaitu sang Patahana Haryadi Suyuti dan mantan GM PSIM Jogja Ahmad Syauqi Soeratno. Nama keduanya muncul karena memiliki tingkat popularitas yang cukup tinggi dan akrab dikalangan Brajamusti, nama Haryadi Suyuti karena selain karena statusnya yang incumbent juga karena dia pernah menjadi Ketua PSIM Jogja, sedangkan nama Ahmad Syauqi Soeratno karena dia merupakan senior Brajamusti dan membawa PSIM menjuarai divisi utama pada tahun 2003 saat menjabat sebagai General Manager

SetelahKPUsecararesmimengumumkan siapa saja yang menjadi calon Walikota dan Wakil Walikota Kotamadya Yogyakarta semua berubah. Dinamika politik yang berlangsung ternyata hanya mengerucutkan dua pasang nama untuk bersaing menjadi nahkoda di Kotamadya Yogyakarta, nama yang muncul adalah pasangan Imam Priyono-Achmad Fadli dan Haryadi Suyuti-Heroe Poerwadi. Tidakada nama Ahmad Syauqi Soeratno sama sekali dalam nama yang telah ditetapkan oleh KPU. Hal ini membuat beberapa anggota Brajamusti menjadi kecewa, tidak sedikit ungkapan kekecewaan pun diluapkan secara terbuka di media social.
Hingga kemudian keluarlah sikap resmi organisasi dari DPP Brajamusti bawa sebagai organisasi non partisan Brajamusti tidak berpihak pada salah satu calon mana pun, tiap anggota Brajamusti dipersilahkan untuk menggunakan hak suaranya secara bebas tanpa ada arahan khusus dari Brajamusti secara organisasi.

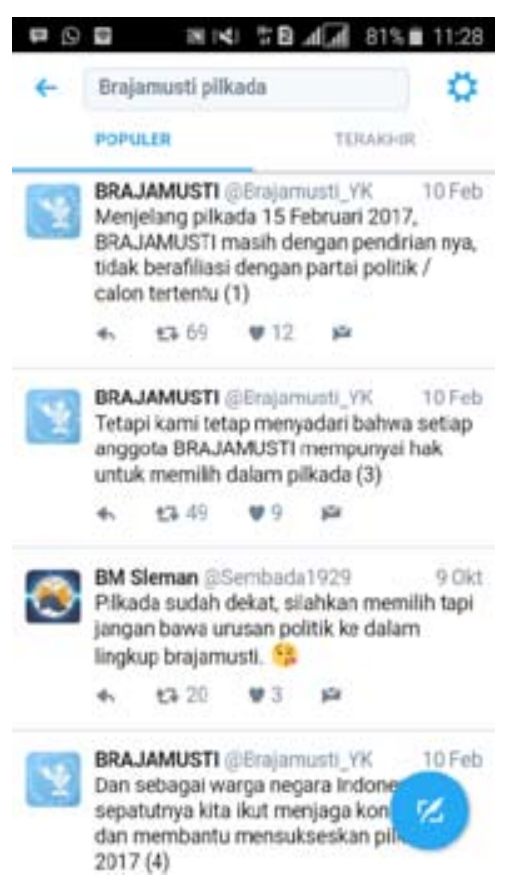

Gambar Pernyataan Sikap Brajamusti secara de jure yang dipublikasikan

Akan tetapi meski sudah ada suara resmi dari DPP Brajamusti terkait sikap organisasi sehubungan dengan pilkada, bukan berarti 
para anggotanya lantas tidak mengambil peran dalam hajat politik tersebut, geliat tetap ada meski tidak membawa nama Brajamusti namun itu semua dilakukandengan semangat untuk kemajuan Brajamusti.

\section{Empat Alur Komunikasi}

Dalam dinamika yang terjadi Brajamusti senantiasa memakai empat alur komunikasi sebagai berikut; Downward Communication, alur komunikasi ini digunakan oleh DPP Brajamusti untuk mendapatkan masukan dari para anggota khususnya yang berada di dalam kumpulan laskar terkait apa saja situasi yang dirasakan dan diinginkan oleh para anggota laskar sehingga keputusan terbaik bisa diambil oleh DPP Brajamusti.

Para laskar pun ketika menyampaikan sebuah pendapat tidak lantas hanya menyampaikan pikiran yang terlintas sesaat, namun setelah melakukan diksusi internal scara komprehensif terlebih dahulu di internal mereka sambil diiringi dengan siskusi yang cukup panjang dengan sosok-sosok yang dianggap mampu mmemberikan masukan yang cukup mencerahkan terkait sikap Brajamusti menjelang Pilkada Kotamadya Yogyakarta.

Dalam pengamatan yang dilakukan oleh peneliti selama masa-masa penjaringan dan kampanye, komunikasi yang dilakukan oleh beberapa laskar cukup intensif dan dilakukan dengan suasana yang sangat kultural sesuai dengan budaya supporter sepak bola Jogja pada umumnya dan berlangsung di tempat yang natural pula, natural dalam artian di tempat-tempat dengan suasana yang memang biasa mereka lakukan untuk bertemu dan bertukar pikiran, sehingga pesan-pesan yang dilontarkan dan yang diterima pun mewakili suasana hati dan jiwa mereka sebagai Brajamusti.

Upward Communication, alur komunikasi ini berlangsung ketika pihak DPP Brajamusti telah selesai melakukan kajian secara mendalam terhadap masukan dan pesan dari para nggota dan mengambil sebuah keputusan terkait sikap Brajamusti secara umum, hasil keputusan yang telah diambil oleh DPP Brajamusti kemudian kembali pada anggota dibawah naungan Brajamusti untukkemudian dilaksanakan bersama-sama.

Namun yang harus disadari adalah bahwa Brajamusti itu bersifat majemuk dan heterogen, mereka berasal dari kumpulan manusi dengan latar belakang yang berbeda satu sama lain dan ada kalanya perberdaan latar belakang diantara mereka sangat mencolok. Sehingga bukan lah sesuatu yang mudah jika dari DPP ingin melakukan sosialisasi pada para aggotanya, rasa kecewa dan curiga tentunya ada namun ada pula yang mengnggap bahwa keputusan dari DPP itu sudah baik, namun meski mereka memiliki perbedaan dalam menilai keputusan dari DPP mereka tetap memiliki satu kesepakatan bersama; apa pun yang kau lakukan, siapa pun yang kau pilih jangan bawa-bawa nama Brajamusti.

Horisontal Communication, mode komunikasi ini berlangsung ketika DPP Brajamusti telah mengeluarkan sebuah kebijakan maka yang harus menaatinya bukan hanya para laskar namun juga Presiden Brajamusti beserta jajarannya. Pertanyaan selanjutnya apakah Presiden dan jajarannnya pun menaati keputusan tersebut, serta bagaimana dengan sikap Brajamolek selaku wadah supporter PSIM lainnya yang menjadi perkumpulan perempuan mandiri namun masih berada dalam afiliasi rajamsuti.

Sikap teladan coba dilakukan oleh Presiden DPP Brajamusti agar para anggotanya dapat menjalani keputusan organsiasi dengan baik. Terlihat selama dinamika politik terjadi sang Presiden menjaga jarak dengan para kandidat yang bertarung dalam konstelasi politik lokal. Apa yang dilakukan oleh Presiden DPP Brajamusti itu cukup konsisten, karena sikap menjaga jarak ini sudah dilakukan jauh sejak masamasa penjaringan. Artinya belum sempat dari KPU memunculkan nama-nama yang secara resmi akan berebut posisi Walikota dan Wakil Walikota Kotamadya Yogyakarta sang Presiden sudah berhati-hati dalam melakukan komunikasi dengan siapa pun yang disebut-sebut akan maju menjadi orang nomor satu di Kotamadya Yogyakarta. 
Terlihat dalam pantauan peneliti ketika KPU telah mengeluarkan surat keputusan resmi siapa saja yang akan maju sebagai calon Walikota dan Wakil Walikota di Kotamadya Yogyakarta, sang Presiden DPP Brajamusti baru kembali membuka diri pada orangorang yang tadinya dia jaga jaraknya karena sudah dipastikan tidak turut bersaing dalam Pilkada 2017.

Sebagai salah satu contoh yang ditemukan oleh peneliti adalah ketika ulang tahun PSIM yang berlangsung pada tanggal 9 Juli 2017 di Wisma PSIM, terlihat Presiden Brajamusti sejak awal acara mendampingi salah satu mantan bakal calon yang turut hadir dalam acara tersebut. Setelah peneliti melakukan konfirmasi memang diakui bahwa pendampingang yang dilakukan oleh sang Presiden DPP Brajamusti itu adalah bentuk teladan yang coba untuk ditanamkan bahwa sang Presiden baru bersedia untuk menunjukkan keakrabannya pada tokoh yang bersangkutan.

Diagonal Communication, mode komunikasi ini terjadi ketika ada sebuah laskar memiliki sebuah gagasan yang dianggap baik maka tak segan-segan laskar-laskar lainnya akan turut memberikan dukungan untuk mengimplementasikan gagasan yang telah dicetuskan itu. Sistem kekerabatan antar laskan dalam Brajamusti cukup unik, antar laskar saling memberikan perlindungan dan dukungan satu sama lain asalkan ada kepastian bahwa laskar yang bersangkutan memperlihatkan keseriusannya dalam mendukung PSIM, dan keseriusan itu dibuktikan dengan bersedianya lascar terebut untuk berada dalam naungan DPP Brajamusti.

Berdasarkan informasi yang peneliti peroleh kesediaan sebuah lascar untuk berada dibawah naungan DPP Brajamusti adalah sebuah jaminan bahwa segala saran yang diususlkan merupakan salah satu uoaya mereka untuk memajukan Brajamusti dan PSIM karena DPP Brajamusti memilikiaturan yang kuat dan megikat. Jadi secara otomatis dianggap bahwa saran yang dicetuskan itu secara otomatis telah melalui filter dariaturan yang diberlakukan leh DPP Brajamusti.
Ketiga, namun meski begitu tetap saja tidak bisa menyingkirkan kekutan komunikasi cultural dan kekuatan dari word of mouth dalam menggerakkan keinginan para anggotanya. Terlihat dengan sudah adanya pernyataan sikap resmi Brajamusti terkait Pilkada 2017yang tidak memihakcalon mana pun, ternyata tidak bisa menghilangkan kegelisahan anggota-anggotanya terkait hasil akhir Pilkada Kotamadya Yogyakarta 2017 hingga tetaplah muncul berbagai wacana dan gerakan untuk memenangkan calontertentu.

Keempat, ada pun dalam kegiatan komunikasi yang melekakan senantiasa menggunakan tiga saluran yaitu; (a) Forum Komunikasi, dengan cara mengadakan pertemuan rutin internal kepengurusn baik di level DPP Brajamusti maupun laskar. Sebagai sebuah organisasi dengan memiliki basis akar rumput yang sangat banyak maka forum komunikasi ini sangat bermanfaat untuk menjadi wadah bertemu dan bertukan pikiran antar lascar yang ada.Keberadaan forum komunikasi ini memiliki bebrapa kelebihan dan kekurangan. Kelebihannya antara lain para laskar dapat bertemu dan tatap muka satu sama lain yang secara otomatis berpotensi untuk memastikan bahwa mereka serius untuk turut hadir dalam forum yang telah disepakati pertemuannya, namun kelemahan dan kekurangan dari keberadaan forum komunikasi ini adalah fakta bahwa Brajamusti itu organisasi majemuk sebagaimana yang telah disebutkan diatas, perbedaan latar belakang tentang siapa-siapa saja yang hadir seolah menjadi tembok pembatas diantara mereka, memang tembok dan sekat itu hilang ketika berada di tribun stadion, namun dalam pertemuan yang bersifat resmi maka ada banyak noise non mekanik yang muncul.

(b) Media Sosial, Brajamusti sebagai organisasi mau pun personal memiliki akun media sosial nya sendiri-sendiri. Memlaui akun ini masing-masing anggota atas nama pribadi mau pun atas nama laskar menuangkan pendapatnya dan kemudian ditanggapi oleh rekan-rekannya yang lain. Namun yang menjadi masalah tersendiri 
adalah karena dunia maya merpuakan dunia yang tidak bisa diukur dan diprediksi secara akurat. Dalam beberapa kasusyang terjadiada saja akun yang mengatasnamakan anggota Brajamusti namun mengeluarkan cuitan yang bernada profokatif dan memunculkan rasa saling curiga satu sama lain, atau jika tidak masalah sering muncul karena urusan noise semantik mengingat berbedanya cara satu orang memahami sebuah pesan yang dilontarkan oleh sebuah akun. Dalam kasus Pilkada di Kotamadya Yogyakarta serangan yang diterima oleh Brajamusti dan bebrapa alskarnya sangat kuat, khususnya dari wadah supporter yang menjadi musuh Brajamusti.

(c) Media Internal, ada sebuah bulletin rutin yang dikeluarkan oleh Brajamusti sebagai media komunikasi merela. Bulletin itu bernama Kabar Mataram yang senantiasa terbit selama dua minggu sekali dengan pertimbangan pertandingan yang berjalan selang-seling kandang dan tandang tiap pekannya. Tabloid ini menjadi kebanggaan tersendiri oleh Brajamusti karena merupakan salah satu simbol bahwa Brajamusti bukan sekedar organisasi perkumpulan tanpa tujuan yang jelas atau hanya perkumpulan untuk menoton pertandingan sepak bola bersama-sama. Namun sebuah wadah yang membuat para anggotanya dapat melahirkan sesuatu yang produktif, tabloid Kabar Mataram adalah salah satu contoh hal produktif yang dihasilkan oleh Brajamusti. Namun yang menjadi masalah adalah sebagai sebuh organsiasi non profit kemunculan Kabar Mataran adakalanya terkendala dana, ada kalanya dalam beberapa waktu Kabar Mataranterlambaterbitkarena permasalahan finansial.

Terakhir adalah adanya kekhawariran pada diri Brajamusti terkait nasib PSIM Jogja ke depan mengingat siapa pun yang memenangkan konstelasi politik lokal di Kotamadya Yogyakarta tidak memiliki catatan yang baik dalam pembangunan PSIM, kisah kelam lima tahun terakhir membayangi Brajamusti dikarenakan tidak adanya tokoh alternatif yang muncul.

Berdasarkan wawancara yang peneliti lakukan kepada senior Brajamusti dan
PSIM Jogja diambil kesimpulan bahwa upaya Brajamusti untuk tampil netral dapat dinilai sebuah pilihan berani yang dilakukan oleh Brajamusti. Mereka lebih memilih mengedepankan independensi organisasi dari pada menjual nama Brajamusti untuk kepentingan politis.

Namun ada dua hal yang harus diperhatkan dari pilihan Brajamusti ini, khususnya dari efek yang ditimbulkan karena plihan politik mereka; pertama Brajamusti telah mengajarkan pada kelompok supporter klub sepak bola lainnya tentang harga diri wadah supporter yang oleh beberapa pihak dianggap sebagai manusia kelas dua dan dapat dijadikan sebagai mesin politik oleh para politisi yang sedang bertarung dalam konstelasi politik. Pendapat bahwa wadah supporter yang oleh beberapa pihak dianggap hanya sebagai sebuah perkumpulan orang-orang tanpa pendidikan politik yang cukup dan cenderung berbuat onar dapat dipatahkan oleh Brajamusti karena sikap independensi mereka, hal ini dapat dikatakan sebuah kemajuan bagi wadah supporter di dunia persepak bolaan tanah air. Besar harapan langkah Brajamusti ini dapat diikuti oleh kelompok lainnya agar tetap menjaga netralitas organisasi sebagai bentuk kecintaan yang nyata kelompok supporter dengan klub yang didukung olehnya.

Kedua, akan tetapi langkah netral Brajamusti ini berpotensi akan menimbulkan sebuah efek yang menbuat Brajamusti akan sedikit kesulitan dalam melakukan akses di pemerintahan daerah untuk berbagai kegiatan mereka di kemudian hari, karena tidak ada pasangan calon yang merasa memiliki komitmen terhadap Brajamusti. Komitmen politik pada umumnya adalah sebuah janji yang dilontarkan oleh pasangan calon tertentu pada sebuah kelompok atau seseorang asalkan kelompok atau atau seseorang ini bersedia mendukung dan mau pun mengerahkan suara demi kepentingan sang pasangan calon, janji politik itu dapat berupa posisi atau pun akses fasilitas yang akan dipersiapkan bagi siapa saja yang bersedia untuk mendukung mereka. 
Akan tetapi dengan netralnya Brajamusti terhadap dua pasangan calon yang ada dalam pilkada di Kotamadya Yogyakarta ini tidak ada siapa pun yang menjanjikan sesuatu pada Brajamusti, maka secara otomasti siapa pun yang memenagkan konstelasi politik lokal tersebut Brajamusti tidak dapat menagihapaapa terhadap pasangan calon yang menang.

Akan tetapi Brajamusti secara organisasi telah membulatkan tekad bahwa mereka lebih memilih untuk tidak memihak pada pasangan calon mana pun dan siap dengan segala tesiko yang akan terjadi. Brajamusti ingin membuktikan bahwa wadah supporter bukan lah kelompok manusia sekunder yang hanya berbuat onar dan keributan serta dapat dipolitisir sebagaimana anggapan beberapa pihak, Brajamusti hendak membuktukan bahwa mereka merupakan kelompok supporter yang memiliki kekreatifitasan dan harga diri yang tinggi serta bisa mandiri untuk terus memberikan dukungan pada PSIM Jogja tanpa menjual suara anggotaanggotanya dalam arena pilkada.

\section{SIMPULAN}

Pertama bagi para supporter di Yogyakarta sepak bola adalah hidup dan kehidupan, sehingga pemilihan kepala derah tidak bisa dilepaskan begitu saja karena akan menetukan nasib klub kesayangan mereka. Tidak menutup kemungkinan hal serupa juga terjadi bagi supporter di daerah lain khususnya bagi klub yang memiliki sejarah panjang.

KeduaJumlahsupporteryangsangatbesar adalah ladang suara yang sangat menjanjikan dalam sebuah pertarungan politik seperti Pilkada. Ketiga Klub yang tidak mandiri dan tidak dikelola dengan profesional berpotensi untuk menjadi lumbung suara oleh para politisi.

Dalam penelitian ini, peneliti memberikan beberapa saran, pertama, bagi para pemenang Pilkada hendaknya memperhatikan nasib klub di daerah karena sepak bola di negeri ini bukan hanya sebuah olah raga namun memiliki makna filosofisnya sendiri bagi para pendukungnya. Apa lagi jika klub yang bersangkutan kaya akan sejarah perjuangan bangsa seperti PSIM, maka berikanlah dukungan terbaik entah itu secara moril maupun materiil.

Kedua bagi para pengurus wadah supporter hendaknya memberkan latihan berpolitik yang cerdas bagi para anggotanya, jangan sampai mereka dipolitisir oleh pihakpihak yang tidak bertanggungjawab hingga salah dalam menentukan pilihan.

Ketiga bagi para pengelola klub hendaknya mulai membiasakan diri untuk bekerja lebih professional, karena klub bukanlah sebuah paguyuban bermain-main. Namun sepakbola adalah sebuah industri yang sangat besar. Kemandirian klub akan menjadikan klub dan para supporter lebih bermartabat sehingga jumlah suarasupporter yang sangat banyak itu tidak dapat dipolitisir sebagai lumbung suara. 


\section{DAFTAR PUSTAKA}

Conboy, Wiliam A. (1976). Communications in a Healthy Organization.Colombus, Ihio: Chas E. Merril.

Junaedi, Fajar. (2011). Media dan Komunikasi Politik. Jakarta: Puskombis UMB Aspikom.

Hardiman,F.Budi.(20o9).MenujuMasyarakat Komunikatif, Ilmu Masyarakat, Politik dan Postmodernisme. Kanisius.

Syahputra, Iswandi. (2016). Pemuja Seoak Bola. Yogyakarta: KPG.

Pace, R. Wayne dan Faules, Don F. (2005). Komunikasi Organisasi: Aliran Komunikasi dalam Organisasi. Bandung: Remaja Rodkarya.

Planty, Earl, dan William Machaver. (1952). Upward Communication: A Project in Excecutive Development. Personnel28, 304-318.

Weick, Karl E.The Social Psychology of Organizing. (1979). New York: McGrawHill.

Harun, Rochajat. (2008). Komunikasi Organisasi. Bandung: CV. Mandar Maju.

Sharma, Jitendra M. (1979). Organizational Communication: A Linking Process. Personnel Administrator, 35-43.

Sukmadinata, Metode Penelitian. (2008). Bandung: Remaja Rosdakarya. 
